Vol. I No. 2 - August 2020

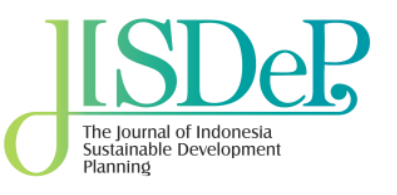

E-ISSN: 2722-0842 | P-ISSN: $\underline{\text { 2721-8309 }}$

Available online at

http://journal.pusbindiklatren.bappenas.go.id/

Kementerian PPN/

Bappenas

Research Paper

\title{
Impact of ICT Adoption on Inequality
}

\section{Evidence from Indonesian Provinces}

\author{
Harry Patria ${ }^{1}$ and Abdul Erumban ${ }^{2}$ \\ University of Indonesia, Depok, Indonesia ${ }^{1}$; University of \\ Groningen, Groningen, Netherlands ${ }^{2}$ \\ harrypatria86@gmail.com; a.a.erumban@rug.nl
}

\begin{abstract}
ב.
Abstract

This study investigates the relationship between ICT adoption ratio and income inequality. While the majority studies explain the impact of ICT on income inequality via labor market, this study offers a different perspective on this relationship. The fast-growing ICT has influenced, not only the employment income, but also the household income, such as property income, consumer surplus, etc. Thus, this study seeks to show the impact of ICT on income inequality via household income channel. The large internet economy and the remarkable internet adoption increase in Indonesia demonstrate the considerable impact of ICT on the lives and income of people in Indonesia. By using panel data regression, this paper shows an inverted U-shape relationship between ICT adoption and income inequality. Low ICT adoption increased income inequality until a certain turning point, whereby higher ICT adoption reduced income inequality in society. The turning point relating to average adoption ratio of mobile phone, computer, and internet was 25\%; while there was an average adoption ratio of $17 \%$ for computer and internet.
\end{abstract}

Keywords: Income Inequality, ICT, Indonesia, household income

ARTICLE INFO
Received: June 10, 2020
Received in revised form: August 3,
2020
Accepted: August 20, 2020

doi: $10.46456 /$ jisdep.v1i2.58
JISDeP - The Journal of Indonesia Sustainable Development Planning Published by Centre for Planners' Development, Education, and Training (Pusbindiklatren),

Ministry of National Development

Planning/ National Development

Planning Agency (Bappenas), Republic

of Indonesia
Address: Jalan Proklamasi 70,

Central Jakarta, Indonesia 10320

Phone: +62 $2131928280 / 3192828$

Fax: +62 2131928281

E-mail: pusbindiklatren@bappenas.go.id

Supported by Indonesian Development Planners Association (PPPI) 


\section{Introduction}

The impact of information, communication, and technology (ICT) adoption on the inequality of income distribution is a widely discussed topic by economists because of the speedy advancement on ICT development nowadays. It is important to pay remarkable attention on this issue as ICT is diffused into almost all aspects of human life and become a key factor on determining the sustainable development. On one side, the ICT diffusion gives benefit on people who use it, but on the other side, it widens the productivity gap between the ICT users and non-ICT users. However, as the prices are lower and more people can afford it, the benefit of ICT is spread to almost all the layers of society and is projected to lower the income inequality level. Therefore, this study provides evidence of the impact of ICT adoption on income inequality.

In recent decades, income inequality within countries is argued to be rising (Atkinson, 2003; Goesling, 2001). Literature has shown that several factors are recognized as the source of income inequality. Technical change is acknowledged as one key element of rising inequality over the world in recent decades. Since most new technologies are skill-intensive, the introduction of new technology leads to a technical change that has a skill-biased characteristic, where skilled workers are preferred and the demand for such workers increase. This leads to a rise in their prices (wages) relative to their unskilled counterparts and leave the employees behind with low wage. ICT is one of the fastest growing technologies that pilots technical change and probably influences inequality in society in recent times.

The use of ICT by producers and consumers across the globe has grown rapidly since the last decade of the $20^{\text {th }}$ century. In the early phases, a lot of literature focused on the impact of ICT use in production and productivity from a producer perspective; however, the involvement of consumers and households in the use of ICT has increased substantially over years. Moreover, the service content of ICT has increased rapidly over the years. There were substantial changes in ICT during the last decade. In this case, the earlier studies discussed about computer and software, nowadays, people talk about cloud computing and ICT services more than a computer. Through these new forms, ICT has influenced almost all aspects of human life such as transportation, services, entertainment, communication, etc. People increasingly use the technology to communicate with others to order transportation services, to make virtual financial transactions, to shop products and services that are delivered to their home, and to access entertainment services. All of them can be done either using their mobile phones or computers.

However, not everyone benefits from the advancement of ICT, as the digital divide or the uneven distribution in the access to ICT across different socio-economic groups still persist (Norris, 2001). This is particularly correct in some developing countries, where the gap between the rich and poor is often large (Chinn \& Fairlie, 2004; Pick, Sarkar, \& Johnson, 2015). Rich people/countries, who have the capital to acquire ICT, have bigger opportunity to enjoy the benefits of the technology quickly, while the poor ones need time to get the benefit of using ICT, to earn more capital to acquire ICT or to wait until the ICT's price is lower and affordable for them (Ziemba, 2016). Even the price of ICT products has gone down drastically, there is still gap on ICT accessibility between the poor and the rich - the digital divide, that will create multiple impacts on society and economy - on growth, poverty, and inequality.

Provinces of Indonesia provide good data that help test the relationship between change in ICT adoption ratio and the change in inequality. With ICT adoption rate varying from the $19.26 \%$ internet adoption ratio in Papua and the $76.96 \%$ internet adoption ration in Jakarta in 2017, ICT adoption ratio among the provinces in Indonesia shows high difference. The internet adoption ratio in Indonesian provinces in 2016 are shown in Figure 1. This data variation is also supported by the average ICT adoption growth in Indonesia, which grew from 30\% in 2012 to more than 45\% in 2016. 


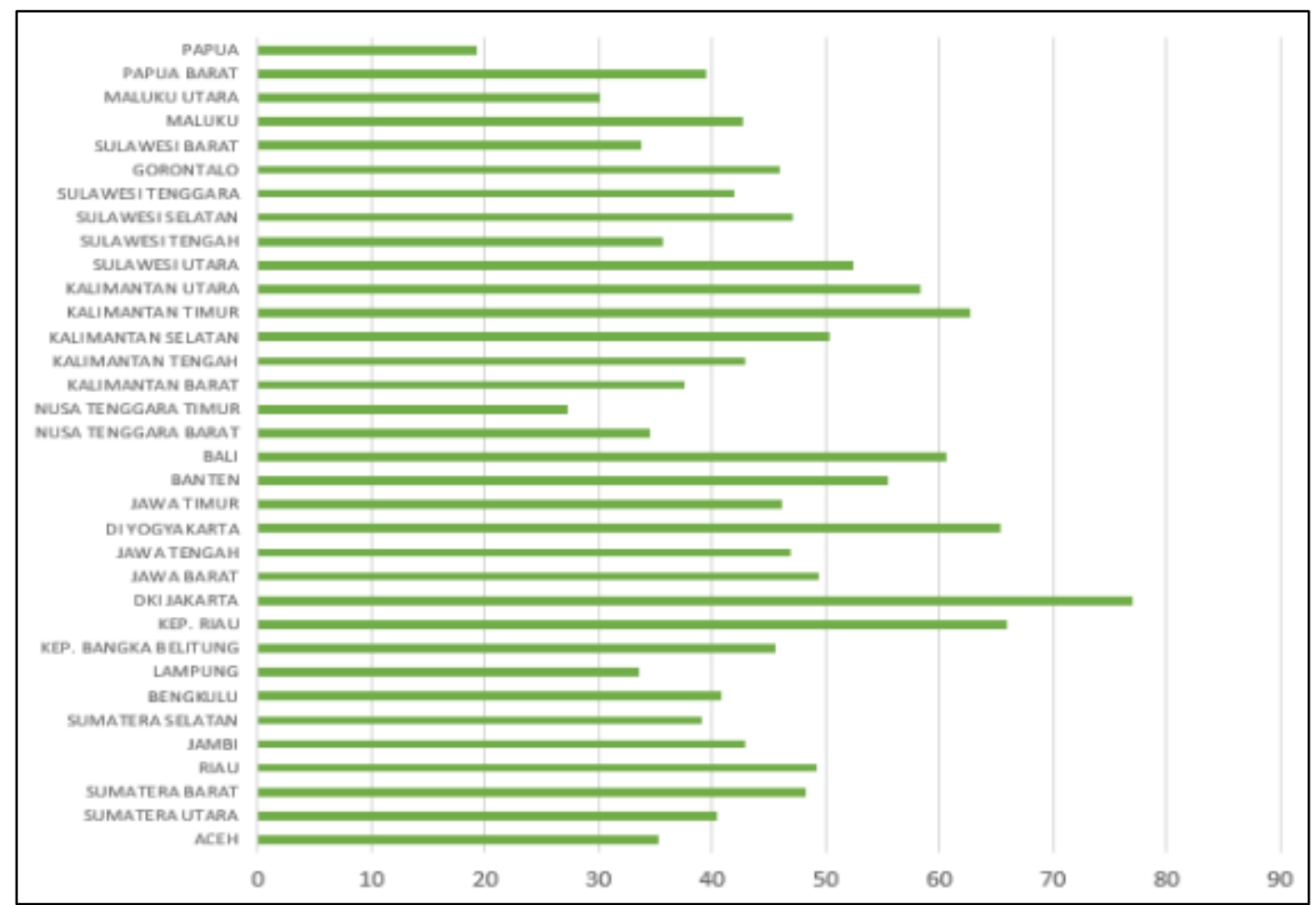

Figure 1. Internet adoption ratio in Indonesian provinces in 2016 (source: bps.go.id)

In addition, the inequality level in Indonesia is on an increasing trend, so it is important to find the determinant of the rising inequality as a way to solve it. By using a panel data of ICT adoption rate and income inequality level in thirty-four provinces from 2012 to 2016, we investigated the relationship between ICT adoption rate and inequality across Indonesian provinces and tested if the inverted U-shaped relationship persists.

\section{Literature Review}

In this section, we reviewed a number of studies related to the impact of ICT on income inequality. However, it is important to take a look at the role of ICT on economic growth previously because one of the channels of ICT influence economic growth is by means of the productivity effect which plays a vital role in determining income inequality. By recognizing that ICT can influence labor productivity, we showed how ICT can influence income inequality in the labor market. This channel has been extensively discussed both in developing and developed countries, as theoretical or empirical studies. Moreover, we provided literature reviews regarding the impact of ICT on households, which reveal the role of ICT on increasing household income. Further, we looked at the impact of ICT on income inequality through the household channel, as the uneven distribution of ICT persists in society.

\subsection{Impact of ICT on Economic Growth}

The onset of new technology can have disruptive effects initially, as envisaged by Schumpeter's famous creative destruction process (1942). New technologies can make existing technologies obsolete faster and firms are forced to discard their capital that uses the existing technology (Abdul Azeez Erumban \& Timmer, 2012). It is during this initial phase of transition that several advanced economies fail to see improvement in productivity. However, once the deployment stage is over and technology is in place, studies have observed the positive impact of ICT on economic growth in three different channels, namely: production effect, investment effect, and productivity effect.

ICT-production sectors have been characterized by rapid technological progress. The Organization for Economic Co-operation and Development (OECD) (2001) showed evidence of a conspicuous increase in Multi-Factor Productivity (MFP) in ICT-producing sectors in the US and Finland from 1990-1999. This 
increasing MFP was then followed by very large economies of scale (Colecchia \& Schreyer, 2003), whereby producing a large number of ICT products, such as semiconductors, made the price of the products lower. Moreover, the capability of advanced technology makes the development of better quality products faster, which in turn influences the price of existing lower quality products to become lower (van Ark, Gupta, \& Erumban, 2013). This price drop further creates considerable increase in demand and contributes to the economy (Ahmed, 2017).

As the price of ICT is decreasing globally, ICT has become more affordable for more firms and industries. Consequently, they are increasing their investment in ICT to gain an increase in MFP (van Ark et al., 2013). By performing growth accounting studies, some researches showed a positive relationship between investment in ICT and economic growth in a country (Cette, MAIRESSE, Kocoglu, \& Mairesse, 2002; Colecchia \& Schreyer, 2003; Abdul A. Erumban \& Das, 2016; Timmer \& van Ark, 2005). Moreover, empirical studies also described the significant positive impact of ICT investment on economic growth (Acharya, 2016; Aghaei \& Rezagholizadeh, 2017; Spiezia, 2013; Stanley, Doucouliagos, \& Steel, 2018).

By using ICT in the production process, labor can perform more efficient work to produce output, therefore, they can increase the amount of output produced. In terms of MFP, ICT provides a better method of combining capital and labor to produce output (van Ark et al., 2013). This study was supported by Oliner and Sichel (2002) and Jorgenson et al. (2002) in the US, Van Ark (2003) in the US and the EU, Faha and Vaumi (2015) in Cameroon and Wamboye et al. (2016) in sub-Saharan countries. Thus, based on the previous studies above, it is clear that ICT plays important role on economic growth and productivity.

\subsection{Impact of ICT on Households}

Instead of only influencing activity in firms and industries, ICT nowadays influences almost all aspects of human life. Countless studies provided evidence of the benefit experienced by households due to the adoption of ICT. For instance, a study asserted that ICT can benefit households by reducing asymmetric information between economic agents (Lindbeck \& Wikstrom, 2000). This argument was supported by another study that presented a literature study on the benefits of the mobile phone by reducing negative factors (e.g. corruption, crimes, expensiveness) and increasing the positive (e.g. education, efficiency, health) through easier access to information and transparency (Bahmani-Oskooee, Hegerty, \& Wilmeth, 2008). Further studies even showed the possibility that household income can be increased by adopting ICT, as shown in Table 1.

Table 1. Literature of the Impact of ICT Adoption on Households

\begin{tabular}{ll}
\hline \multicolumn{1}{c}{ Authors } & \multicolumn{1}{c}{ Impact of ICT adoption on households } \\
\hline Irvine \& Anderson (2008) & Increasing efficiency of the business process in hospitality services in Scotland \\
\hline Cramer \& Krueger (2016) & $\begin{array}{l}\text { Greater utilization of ICT-equipped taxi driver (Uber) than the conventional taxi } \\
\text { driver in the US during 2014-2015 }\end{array}$ \\
\hline McNamara (2003) & $\begin{array}{l}\text { Learning better methods for producing, pricing and marketing their products } \\
\text { and connecting them to the government to match their needs and the services } \\
\text { provided }\end{array}$ \\
\hline Mbuyisa \& Leonard (2017) & $\begin{array}{l}\text { Increasing market access, reducing production costs, and rising efficiency on } \\
\text { information gathering }\end{array}$ \\
\hline Flor (2016) & $\begin{array}{l}\text { Reducing transportation cost, providing updated information, increasing } \\
\text { networking, making it easier to run personal businesses and increase security }\end{array}$ \\
\hline Hübler \& Hartje (2016) & $\begin{array}{l}\text { Information exchange, providing a job, weather information, mobile financial } \\
\text { transactions, social networks, etc. }\end{array}$ \\
\hline Cecchini (2003) & Having better access to markets, health, education, and financial services \\
\hline Silva \& Ratnadiwakara (2008) & Possibility of reducing transaction costs significantly by providing access to ICTs \\
\hline Monga, Lin, Aker, \& & Information sharing, money transfers, saving money and as devices to use in \\
Blumenstock (2014) & learning \\
\hline Brynjolfsson, Hu, \& Smith & Improving efficiency on book markets \\
(2003) & Positive net consumer welfare of using mobile instant messenger in Korea \\
\hline Kim (2018) & Consumer surplus in digital content delivery services \\
\hline Byrne \& Corrado (2017) &
\end{tabular}


From these studies, we can see that there are numerous advantages to be gained by households adopting ICT instead of just an increase in employment income. However, household incomes cover all of the ICT benefits in property income as other income from other non-financial assets. By looking at ICT adoption at the household level, we can measure the households that experience income increases as a result of ICT.

\subsection{Impact of ICT on Income Inequality}

As previously mentioned, the diffusion of ICT is advantageous for economic growth by increasing productivity, both in industries and in households. However, there is a growing concern about the impact of this increasing productivity on income inequality, seeing as ICT does not benefit all types of workers in industries and the presence of the 'digital divide' at the household level.

Most of studies used the labor market channel to measure the impact of ICT on income inequality. The skill-biased characteristics of technology is suggested as the main reason for changes in the wage structure (Bound \& Johnson, 1989). Computer technology plays a crucial role in increasing demand for high-skilled laborers relative to the medium-skilled and low-skilled laborers (Autor, Katz, \& Krueger, 1997). Further research showed that the introduction of new technology might increase the wages of high skill laborers and reduce the wages of laborers whose jobs can be replaced by new technology (Acemoglu \& Autor, 2010). This study is supported by Michaels Guy \& Natraj Ashwini (2014) stating that there was a shift in demand from medium-skilled labor to high-skilled labor in fast-growing ICT industries in the US, Japan and nine European countries from 1980 until 2004.

Some other studies tried to offer a different perspective on the relationship between ICT and income inequality. Uneven ICT distribution among households means that only a limited number of people can enjoy the benefits of ICT and increase their income. In this situation, there will be an increasing income gap between households with ICT and ones without ICT (Bourdeau de Fontenay \& Beltran, 2008; Ziemba, 2016). However, as the adoption of ICT has increased, more people benefit and earn higher incomes, which in turn further reducing the income inequality level. Asongu (2015) highlighted the positive income equalizing effect of mobile phones in 52 African countries from 2002-2009. A further study used the mobile phone as the proxy of ICT to study its impact on income distribution between eleven countries in Africa in 2011. By involving not only the adoption rate but also the intensive use of mobile phones, this study found that mobile phone usage has an income equalizing effect between countries (James, 2014). The summary of the channels of ICT influence income inequality is shown in Figure 2.

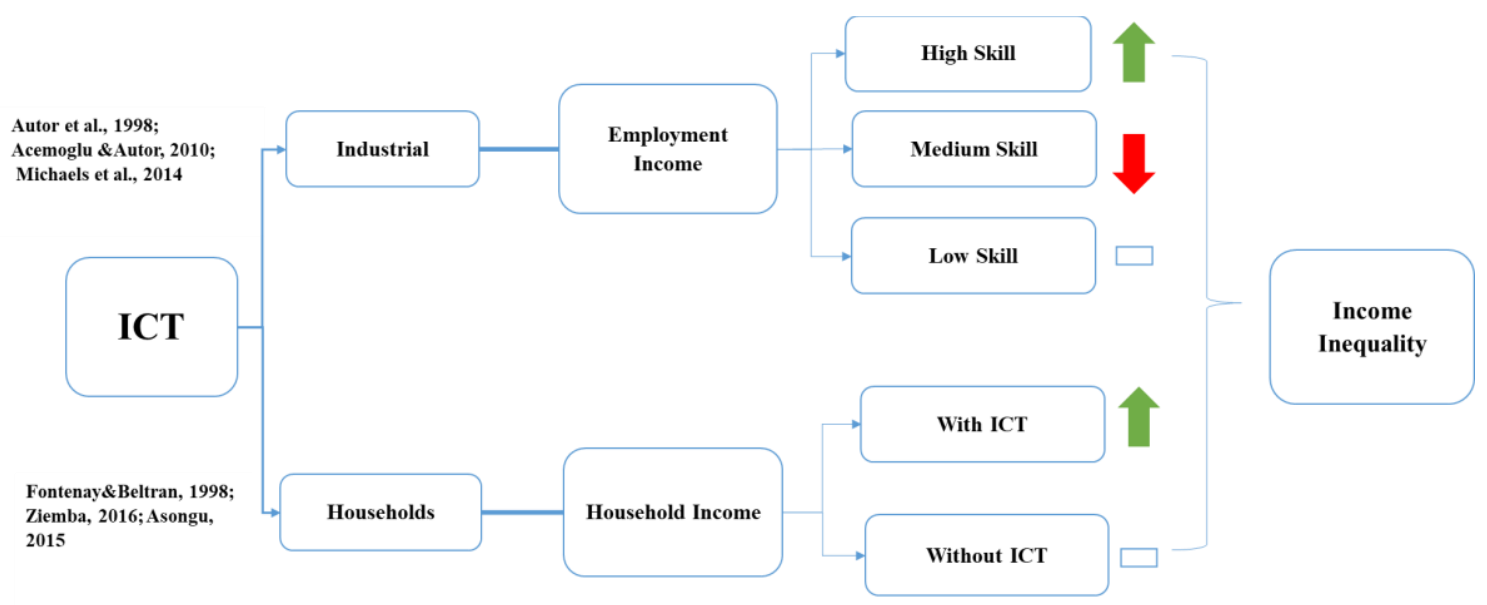

Figure 2. The summary of the channels of ICT influence income inequality (source: author)

In the light of the interesting previous literature, we were unable to find any study about the impact of ICT adoption on income inequality in Indonesia. The most prominent channel of the relationship 
between ICT and income inequality, as identified by the previous literature, is by way of the supply side/labor market, but the benefit of ICT for households and the presence of the digital divide might also play a vital role in determining income inequality. While the income inequality study via labor market is widely available, the household channel, which can also change the income structure by reducing transaction cost, provide consumer surplus, etc., gets less attention. It is important to do this study because ICT diffusion influences almost all the aspects of human life instead of just in labor market. In 2019 , Indonesia was recorded as the largest internet economy in the world with US\$27 billion economic value and $49 \%$ compound annual growth rate during 2015-2018. In addition, four technology companies in Indonesia turned out to be billion dollars "unicorn" and became part of 300 biggest technology companies in the world. This diffusion changes not only the wage of labor, but also change the income structure in household level. Given the data limitations about the wage structure in Indonesia, we were not able to investigate the impact of ICT adoption on income inequality in the labor market. Therefore, this study examined the impact of ICT adoption in households on income inequality in Indonesia. In addition, the relationship between ICT adoption and income inequality remains unclear because some studies showed the possibility of ICT increasing income inequality (Bourdeau de Fontenay \& Beltran, 2008; Ziemba, 2016), though other researches demonstrated the equalizing effect of ICT on income distribution (Asongu, 2015; James, 2014). Therefore, in this case, there might be an opportunity to implement the inverted U-shaped relationship of economic growth on income inequality introduced by Kuznets (1955).

\section{Methodology}

By observing the household adoption rate of ICT, we can get information about how far people, which are assumed to have a low capability on acquiring ICT, get benefit from ICT, where a high adoption ratio shows that more poor people gain the advantage from ICT. By controlling other factors that affect inequality, the effectiveness of newly-adopted (people who do not access ICT in previous periods) using ICT to increase their income and influence the gap to the rich. This study provided a contribution in three ways, namely: adding literature about the determinants of income inequality in Indonesia, providing empirical evidence about income inequality in the regional study, and showing the probability of inverted U-shape relationship between ICT adoption ratio and income inequality.

\subsection{Hypotheses}

In this study, we sought to answer the impact of ICT adoption ratio on income inequality in Indonesian provinces. For this, we used data of Indonesian provinces (the whole data used in this study was collected from the Indonesian Bureau of Statistic (bps.go.id) on Dynamic Table session) because of the variation in ICT adoption ratio and the data availability. After reviewing the existing studies related to the impact of ICT, we postulated the following hypotheses:

"The change of ICT adoption rate has a significant impact on the change of income inequality in Indonesia and the relationship is inverted U-shaped. At low adoption rate, the income gap between those who have access to the technology and those who do not will increase. Meanwhile, high ICT adoption rate means that more people enjoy the advantage of ICT that will reduce the income gap in society."

In this research, we used the mobile phone, computer, and internet access as the proxies of ICT because these devices are the most common ICT products that are used by households compared to other kinds of ICT proxies. Most of ICT benefits can be obtained by using a mobile phone. Nonetheless, the mobile phone has limited capacity to increase people productivity. A computer has better capacity on increasing productivity; however, to access ICT and gain benefit from it, a computer needs internet access.

The research method should be appropriate with the statement of the research problem. It should cover method used, measurement instrument, sampling method, data collection technique and data analysis. Data are described and adequate. 


\subsection{Methodology}

Since the objective of the thesis was to understand the impact of ICT penetration on income inequality, we needed to measure income inequality, ICT and several possible control variables. We used the Gini coefficient as a measurement of income inequality, and multiple indicators including mobile phone, personal computer, and internet adoption ratio to capture the ICT adoption as a main explanatory variable. The study was a year of schooling, unemployment ratio, price index, and foreign direct investment in each province used as control variables that may have a significant impact on inequality.

The model we used in this thesis postulated a relationship between income inequality and ICT adoption, whether higher adoption ratios had any impact on income inequality. In addition, we also hypothesized that the impact of ICT adoption ratio on income inequality can be an inverted U-shape. Thus, we expected a positive significant impact of ICT on income inequality in low ICT adoption ratio, but a negative significant impact of ICT on income inequality in high ICT adoption ratio. To test the significant impact of ICT adoption on income inequality in Indonesian provinces, we followed the model that was used by (Dartanto, Yuan, \& Sofiyandi, 2017) to measure the impact of structural change on income inequality and add ICT variables into the model. Moreover, to test if the relationship is inverted U-shape, we added the ICT square variable into the model. A positive impact of ICT and a negative impact of ICT square variables on inequality implied an inverted U-shape relationship between ICT and inequality.

$$
\begin{aligned}
& \operatorname{lnGINI}_{i t}=\alpha_{i}+\beta_{1} \operatorname{lnICT}_{i t}+\beta_{2} \operatorname{lnICT}_{i t}{ }^{2}+\beta_{3} R G D P_{i t}+\beta_{4} A G R I_{i t}+\beta_{5} M A N U_{i t}+\beta_{6} F N_{i t}+\beta_{7} G O V_{i t} \\
& +\beta_{8} E D U_{i t}+\beta_{9} U N E M P_{i t}+\beta_{10} P R I C E_{i t}+\beta_{11} F D I_{i t}+\beta_{12} P O V_{i t}+\varepsilon
\end{aligned}
$$

InGINI : the log of Gini coefficient.

LnICT : the average of log of adoption rate of mobile phone, computer, and internet

RGDP : real GDP per capita (in thousand US dollar)

AGRI : share of agriculture on GDP (percentage)

MANU : share of manufacture on GDP (percentage)

FIN : share of finance on GDP (percentage)

GOV : share of government expenditure on GDP (percentage)

EDU : average years of schooling

UNEMP : Open Unemployment Ratio (percentage)

PRICE : Price Index

FDI : Foreign Direct Investment Ratio to GDP

POV : Poverty Rate

i : province, $\mathrm{i}=1, \ldots, 33$

t $\quad$ : year $\mathrm{t}=2012,2013, \ldots, 2016$

Since our data consist of 33 provinces and five years, we used a panel data analysis. A panel data can be estimated using pooled OLS (POLS), fixed effects (FE), or random effects (RE) estimation methods. The main difference between these methods can be found in the assumption of the coefficients of the variable. While POLS assumes that coefficients $\beta_{1} \beta_{2} \beta_{3}$ do not differ between individuals $\left(y_{i t}=\beta_{1}+\beta_{2} x_{2 i t}+\beta_{3}\right.$ $\mathrm{x}_{3 \mathrm{it}}+\varepsilon_{\mathrm{it}}$ ), FE assumes different intercepts $\beta_{1 \mathrm{i}}$ between individuals but keep a constant slope coefficients $\beta_{2}$ $\beta_{3}\left(y_{i t}=\beta_{1 i}+\beta_{2} x_{2 i t}+\beta_{3} x_{3 i t}+\varepsilon_{i t}\right)$. In RE, all individuals differences are captured by the intercept coefficient $\left(\beta_{1 i}=\beta_{1}+u_{i}\right)$ but presented as an average and random value so the model l become $y_{i t}=\beta_{1}+\beta_{2} x_{2 i t}+\beta_{3} x_{3 i t}+v_{i t}$, where $v_{i t}=\varepsilon_{i t}+u_{i t}$. FE is chosen if we are interested on individual effects of the sample, while RE is preferred if the individual effects is not our interest. Moreover, POLS is preferred when there are no random or fixed individual differences among sample members. However, in our study, we did a number of statistical tests to make the appropriate choice, namely:

1. Chow test to choose between POLS and FE,

2. Hausman test to choose between FE and RE, and

3. Lagrange Multiplier (LM) test to choose between POLS and RE. 
Besides, we considered the impact of control variables on income inequality. A good empirical model provides a significant result on control variables as in the literature review. Thus, the significance of control variables was also considered to choose the model in this study.

\subsection{Data and Variables}

The whole data used in this study were collected from the Indonesian Bureau of Statistic (bps.go.id) on Dynamic Table session. Since the objective of the thesis is to understand the impact of ICT penetration on income inequality, we needed to measure income inequality, ICT and several possible control variables. We used the Gini coefficient as a measurement of income inequality, and multiple indicators including mobile phone, personal computer, and internet adoption ratio to capture the ICT adoption as a main explanatory variable. The study was conducted across 33 provinces across Indonesia in the period of 20122016. In addition, real GDP per capita, the share of agriculture, manufacture, finance, trade, and government on GDP, poverty rate, average years of schooling, unemployment ratio, price index, and foreign direct investment in each province were used as control variables that may have a significant impact on inequality.

Gini Coefficient (GINI) is the most common indicator used to measure income inequality. This coefficient is obtained from the Lorenz curve, which is the sort of people from the lowest income to the highest income in a country or region and shows the population accumulation in axis $x$ and the income accumulation in axis $y$. If the value of GINI is one, the population is considered to have perfect inequality, while zero indicates a perfectly equal population. There are some other measurements that are used to estimate the inequality, such as top 1 percent and top 10 percent income, Interdecile p50/p10, Palma ratio, s80/s20 quintile ratio, etc. We used GINI in this study because of the availability of the data. Indonesian Bureau of Statistic provided data on Gini coefficient for urban area, rural area, and the combination of both areas. The website (bps.go.id) provide an option for Gini coefficient for the first and second half of the year and also for the whole year, from 2002 until 2018. However, the data are only available for the first half year, while the second half and the whole year's option resulted in no data. For this study, we used the combined data of both rural and urban areas that represented the whole condition of a province in Indonesia. We used the period of 2012-2016 because of the lack of data on some other indicators. It is important to evaluate whether the analysis should address the research problem or not. Analysis should also address the implications and link to the research problem. The argument should be also based on the strong theoretical framework, data and valid information.

Average ICT adoption ratio (ICT): The average value of mobile phone, computer, and internet adoption ratio in a province in Indonesia, where mobile phone adoption ratio shows the percentage of households that own or have the right to use a mobile phone in a province; computer adoption ratio indicates the percentage of households that own or have the right to use a personal computer in a province; and internet access ratio offers the ratio between the number of households that access the internet at least once in the last three months before the survey was done and the total number of households in a province. The use of these three tools as proxies of ICT is important because they are the most general and affordable ICT devices that can be used by households to access the benefit of ICT. However, mobile phone adoption ratio does not provide information regarding the type of mobile phone that is owned by households, in which smartphone provides a larger benefit than a conventional mobile phone. An increase in the average ICT adoption ratio shows that there are new people who use ICT in their daily life and be exposed by the benefit of ICT.

In this study, we assumed that increasing income inequality in low average ICT adoption ratio because, in the early phase, only rich people had access to ICT, while the poor left behind and led to a wide gap between them. However, as the adoption ratio increases, more people have access to ICT and enjoy the benefit of ICT that elevate their whole life quality and finally reduce the welfare gap in society. Therefore, in this study, we assumed a positive significant relationship between ICT and GINI, and negative significant relationship between ICT2 and GINI.

Regional Gross Domestic Product (RGDP): Regional gross domestic products provide the per capita expenditure in each province during 2012-2016. This variable used constant price in 2010. The importance 
of this economic indicator was pretty clear in some studies, but the direction of the impact was ambiguous because some studies showed a positive impact of economic growth to income equality, while the others explained different situations.

Economic Structure (AGRI, MANU, FIN, GOV, TRADE): The GDP share of agricultural, manufacturing, financial service, government expenditure, and trade sector on total GDP. It is important to control these indicators because some studies showed the impact of structural economic changes to inequality, where the shift from agriculture to manufacturing, agriculture to services, and manufacture to services increased income inequality in Indonesia. Moreover, an increase in government share means that the government has more money to solve the social problems exists in society, where income inequality is one of the problems. Trade plays an essential part in the Indonesian economy because of the high number of small and medium enterprises (SMEs) in Indonesia. Previous studies showed that a higher share of trade sector on GDP reduced the income inequality.

Poverty Rate (POV): Number of people who live under the poverty line in a province in Indonesia. This poverty line is the summation of food and non-food poverty lines, where the food poverty line is described as the minimum expenditure that must be spent by an individual to gain 2,100 kilocalorie food per capita per day and the non-food poverty line is the minimum expenditure to gain commodity such as housing, clothing, education, and health, based on Basic Needs Commodity Package Survey 2014 in Indonesia. There are two periods of time available for this data yearly, first and second half-year. For this study, we used the average of the first and second half year. An increase in poverty rate means a lower average income in society that will increase income inequality.

Average Years of Schooling (EDU): The average years of schooling for people with age more than 15 years in a province. Finishing basic school is measured as a six-years of schooling, finishing primary high school is measured as a nine-years of schooling, and finishing secondary high school is measured as a twelve-years of schooling, without considering any longer times of schooling in those schools. Higher education is measured as the years attempted in certificates. Higher education level is expected to have a negative significant relationship on income inequality.

Unemployment Rate (UNEMP): The percentage of the workforce that does not have a job, including people that are still seeking for a job, getting ready to be an entrepreneur, not seeking for the job because they think that they will not have any job, and people that have a job, but don't start to work. This concept is based on the ILO Manual and Concept Methods. There are three options of data that are provided in Indonesia's Bureau of Statistics website, namely: February, August, and yearly data. In this study, we used the average between February and August data because the yearly data was currently not available. Existing studies indicated a positive relationship between unemployment condition with inequality, where high unemployment level led to high income inequality.

Inflation Rate (PRICE): Inflation rate is the change in the prices of goods and services. If the change in the domestic price of goods and services increases, the inflation rate increases. This increasing price will result in a lower value of the domestic currency in term of the general value of goods and services. In this study, we used the data of the general price index to describe inflation with the year 2010 as the base year (price=100). The data were available for some cities in a province, but in this study, we used the data of the capital city of each province. Based on previous studies, we assumed a negative impact of inflation on income inequality.

Foreign Direct Investment (FDI): total investment from foreign countries that come to a province in one year. This investment was measured in million US dollars. The previous study offered a positive effect of foreign direct investment on income inequality. 
The summary of the data used in this study is shown in Table 2.

Table 2. Hausman and Breusch and Pagan Lagrangian Multiplier Tests Results

\begin{tabular}{lccccc}
\hline \multicolumn{1}{c}{ Variable } & Observation & Mean & Std. Dev. & Min & Max \\
\hline InGINI & 165 & -.990 & .105 & -1.290 & -.816 \\
\hline InICT & 165 & 3.594 & .265 & 2.788 & 4.168 \\
\hline InICT2 & 165 & 12.988 & 1.880 & 7.772 & 17.370 \\
\hline RGDP1000 & 165 & 35.806 & 28.557 & 10.031 & 149.848 \\
\hline AGRI & 165 & 20.035 & 9.664 & .090 .090 & 41.901 \\
\hline MANU & 165 & 15.837 & 11.226 & 1.248 & 43.720 \\
\hline FIN & 165 & 2.951 & 1.574 & .862 & 10.928 \\
\hline GOV & 165 & 6.037 & 3.945 & 1.631 & 20.162 \\
\hline TRADE & 165 & 12.002 & 3.479 & 4.586 & 18.381 \\
\hline EDU & 165 & 7.923 & .972 & 5.73 & 10.88 \\
\hline UNEMP & 165 & 5.044 & 2.258 & 1.37 & 10.68 \\
\hline PRICE & 165 & 125.586 & 11.380 & 108.43 & 152 \\
\hline FDIR & 165 & .514 & .828 & .001 & 6.970 \\
\hline POV & 165 & 11.997 & 6.282 & 3.635 & 31.33 \\
\hline \multicolumn{1}{c}{ source: bps.go.id (calculated by author) } & & &
\end{tabular}

\section{Results}

We did some regressions following the formulated model. In doing the regression, we did it by using full model as we included all the ICT variables in regression, and partial models where we relaxed one ICT proxies to see the impact of one ICT without the existence of other ICT tools. Moreover, we relaxed the education variable to avoid the presence of endogeneity problem because education might influence other independent variables. After doing Hausman and Lagrange tests to choose a preferred regression approach, we decided to use random effects method because the full model shows a weakly significant result of the difference in coefficients. Even though the result was significant when we removed the mobile phone in measuring the average ICT adoption, we kept using the random effect to make it comparable with the full model. Moreover, we considered that there were no specific characteristics in each province that influenced the regional inequality level. The results of the tests are shown in Table 3.

Table 3. Hausman and Breusch and Pagan Lagrangian Multiplier Tests Results

\begin{tabular}{|c|c|c|c|c|}
\hline & Full Model & COM+INT & Full Model-EDU & COM+INT-EDU \\
\hline \multicolumn{5}{|l|}{ Hausman Test } \\
\hline Chi2 & 21.20 & 31.43 & 18.24 & 53.59 \\
\hline Prob>chi2 & 0.0476 & 0.0029 & 0.0762 & 0.0000 \\
\hline \multicolumn{5}{|c|}{ Breusch and Pagan Lagrangian Test } \\
\hline Chibar2 & 102.05 & 94.41 & 109.98 & 103.09 \\
\hline Prob>chibar2 & 0.0000 & 0.0000 & 0.0000 & 0.0000 \\
\hline
\end{tabular}

By using the random effects approach, we got the regression result as shown in Table 4.

Table 4. Regression Result

\begin{tabular}{lllll}
\hline Variable & Full Model & COM+INT & Full Model-EDU & COM+INT-EDU \\
\hline InICT & $.9604^{*}$ & & $.9471^{*}$ & $-.1506^{* *}$ \\
InICT2 & $-.1536^{* *}$ & & & $.5657^{* *}$ \\
InCOMINT & & $.5713^{* *}$ & $-.1043^{* *}$ \\
InCOMINT2 & & $-.1059^{* *}$ & -.0010 \\
RGDP1000 & -.0012 & -.0011 & -.0010 & -.0022 \\
AGRI & -.0024 & -.0023 & -.0022 & .0019 \\
MANU & .0018 & .0018 & .0018 & $.0537^{* * *}$ \\
FIN & $.0518^{* * *}$ & $.0533^{* * *}$ & $.0522^{* * *}$ & $-.0093^{* *}$ \\
GOV & $-.0103^{* *}$ & $-.0100^{* *}$ & $-.0095^{* *}$ & $-.0166^{* * *}$ \\
TRADE & $-.0165^{* * *}$ & $-.0167^{* * *}$ & $-.0163^{* * *}$ & .0027 \\
EDU & .0113 & .0101 & & .0001 \\
UNEMP & .0025 & .0025 & .0028 & -.0032 \\
PRICE & .0000 & .0001 & .0000 & $.0069^{* * *}$ \\
FDIRATIO & -.0032 & -.003 & -.0031 & $-1.6858^{* * *}$ \\
POV & $.0073^{* * *}$ & $.0076^{* * *}$ & $.0066^{* * *}$ & 165 \\
Cons & $-2.4725^{* * *}$ & $-1.7584^{* * *}$ & $-2.2856^{* * *}$ & \\
Observations & 165 & 165 & 165 &
\end{tabular}


The regression result of the full model show that when we included all the variables and measured average ICT adoption as the average adoption in mobile phone, computer, and internet adoption, the adoption rate offered weakly significant positive impact of ICT adoption on income inequality, meaning that the increase in ICT adoption would increase income inequality in Indonesian provinces. After excluding the mobile phone adoption ratio from the average ICT adoption, we found that the impact of ICT adoption became stronger, but with a lower coefficient. This might happen because we could not distinguish the types of mobile phone used by the households, either a conventional mobile phone or a smartphone, where a smartphone provides higher benefit for the users than the conventional one. One percent increase on the average percentage of computer and internet adoption increased the Gini coefficient by 0.57 percent; meanwhile, one percent increase on the average percentage of mobile phone, computer, and internet adoption increased the Gini coefficient by 0.96 percent. However, the significant negative impact of the square of ICT adoption on income inequality showed the inverted U-shape relationship between ICT adoption and income inequality. With this inverted U-shape relationship, we could calculate the turnover value of the log of average ICT adoption, which was beyond this average ICT adoption, and an increase in ICT adoption lowered the income inequality. By assuming the first difference of the Gini was equal to zero, we calculated the turning point of the log of ICT adoption as: (1) the average mobile phone, computer, and internet adoption: $22.79 \%$; and (2) the average computer, and internet adoption: $14.84 \%$.

Therefore, by reaching the average ICT adoption ratio for mobile phone, computer, and internet by 22.79 percent or average adoption of computer and internet by 14.84 percent, ICT could have a positive impact on income equality. This result is in line with Kuznets' inverted U-shape relationship of economic growth and income inequality to the relationship between ICT adoption and income inequality. This is probably because of the similar characteristic of economic growth and ICT, where both of them can be beneficial for poor people if only the distribution experienced by the poor. While the distribution of economic growth was not easy to measure, the distribution of ICT can be reflected in ICT adoption ratio, where the rich usually adopt ICT earlier. A high ICT adoption ratio implied a well-distributed ICT that made a negative impact of ICT on income inequality in society. This finding is in line with the studies stating that ICT is beneficial for households (Hübler \& Hartje, 2016; Lindbeck \& Wikstrom, 2000). This also supports the poverty reduction function of ICT (Agüero \& de Silva, 2011; Cecchini, 2003; Jensen, 2007; Mbuyisa \& Leonard, 2017; McNamara, 2003). Thus, this paper provided the behavior of how ICT adoption can help poor people in Indonesia.

Moreover, the insignificant impact of real GDP per capita on inequality denied the previous study that used the US as the object (Panizza, 1999). This might occur due to a different characteristic of Indonesia and the US, where Indonesia is an developing country and the US is a developed country; wherein developed countries, the income might have distributed more equal compared to the distribution in developing countries. However, this unimportant role of economic growth on determining income inequality was also found in previous study (Bahmani-Oskooee et al., 2008).

Economic structure, which has a critical function on settling the income inequality in Indonesia (Afandi, Rantung, \& Marashdeh, 2017; Dartanto et al., 2017; Novalia, 2014), also showed an essential part on this study. Even agriculture and manufacture do not provide a significant impact on income inequality, the financial sector which is considered as a service sector shows a positive significant effect on income inequality. This was probably because this service sector usually required high-skilled workers, so an increasing share in this sector will increase the demand of this type of labor and finally raise their income which will finally expand the gap with the low-skilled workers. The role of the government sector on controlling inequality is clearly seen in this study. In this case, an increase in government shares on GDP decreased inequality among society. This finding supports the research that the government has an important part of providing ICT for the poor to reduce poverty (Flor, 2016). As a democratic country, all resources in Indonesia that are essential for society are managed by the country for people interest. As ICT is one of central resource needed by public, government play important role on regulating it. Yet, ICT is not the only tool for the government to reduce poverty and increase inequality. Another economic structure variable, the share of trade on GDP, also participate in specifying the inequality level. Rise of the trade portion on GDP will reduce the inequality within the society. This might relate to the high segment of small and medium enterprises (SMEs) in Indonesia, hence an increasing portion of trade means that more poor people engage in trades that probably increase their life quality and reduce the income inequality. 
Education surprisingly became insignificant factors to influence income inequality in Indonesian provinces. This result opposed the existing literature studies that explicate the importance of human capital on alleviating poverty. Actually, this immaterial role of education also happened in a study of income inequality in Indonesia (Dartanto et al., 2017). The low average years of schooling in Indonesia might cause this unimportant role of human capital on influence inequality. As described in the data description, the average years of schooling in Indonesia are less than 8 years, which means that more than half of the young people in Indonesia do not graduate from a secondary high school. Different from existing literature, unemployment was a minor aspect to influence income inequality in Indonesia (Akinbobola \& Saibu, 2004). This might correlate with the finding stating that unemployment can make an impact on inequality in case of extreme inequality, while the inequality in Indonesian provinces was not extreme (Tregenna, 2011). This finding is also in line with a study that didn't find any systematic relationship between income inequality and unemployment (Saunders, 2002). The low average income level in Indonesian provinces might be the reason for the insignificant impact of unemployment on income inequality. The low average income and non-extreme inequality provided small gap between the employed and the unemployed people, where the change of unemployed people did not influence the gap that was already small.

Inflation, in the form of the price index, also performed a little part in determining income inequality in this study. The possible explanation for this condition is that inflation influences almost all levels of society. Even though the literatures explain the equalizing effect of inflation because of its benefit for the middle-income people (Adam \& Zhu, 2016; Meh \& Terajima, 2011), it also creates a loss for the poor people that severe the income inequality between the middle income and the poor. As a result, the gap between the rich and middle-income people got closer, but the gap between the middle-income people and the poor got wider.

The incoming investment to Indonesian provinces does not provide essential impact on inequality in Indonesia provinces. This fact declines the study that FDI influence inequality through the transfer of technology that leads to skill-biased technological change (Lee \& Wie, 2015). In this study, a low level of transfer of knowledge can be considered as the main aspect in a small impact of FDI to inequality. In this study, we can see that it is not only the level of incoming investment that influence the income inequality. Transfer of knowledge that is embedded in FDI must also be considered on measuring the relationship between incoming FDI and income inequality.

\section{Conclusions}

Income inequality is always an important issue in a country because of its essential impact on economy and society. Many studies have been done to find out the determinants as a way to find the solution to this problem. However, there is a limited number of studies performed to revise the income inequality determinants in Indonesia. On the other hand, the increasing diffusion of ICT in society shows its rising needs for a better life. The growing significance of ICT on determining the quality of life might also influence the income inequality condition in a region. By looking at the ICT adoption ratio, we get the description of the distribution of ICT among the households in Indonesian provinces. Well-distributed ICT will increase the number of people who can enjoy the benefit of ICT and increase their life quality. This study contributed on providing more literature about the determinants of inequality in Indonesia and supporting the possibilities of an inverted U-shape relationship between ICT adoption and income inequality. By knowing the turning point of the inverted $U$-shape relationship, we can get a minimum ICT adoption ratio that must be achieved to reduce income inequality in society, otherwise, the ICT will increase the income inequality.

There are three important points that can be taken from this empirical study of 33 provinces in Indonesia during 2012-2016. First, ICT adoption rate is important to determine the level of income inequality in Indonesia. From the regression result, we get that ICT adoption has two different effects on income inequality. On one hand, it increases the income inequality, but on the other hand, the effect is slowing as the adoption rate increase. Because of the existence of these opposite effects, ICT adoption will give no impact on income inequality in a certain point. By passing this certain ICT adoption level, government can use ICT to reduce income inequality in society. Second, it is important for the government to reach about 23 percent of the average adoption rate of mobile phone, computer, and internet or about 15 percent of the average adoption rate of computer, and internet to generate a positive impact of ICT on inequality. Third, the government can support the trade sector to increase reduce inequality in society. 
There are some developments that can be done to support this study. Categorizing the speed of internet, the type of mobile phone and computer, or the coverage of internet in sample area will provide a more accurate result on the impact of ICT adoption on income inequality. Moreover, a more sophisticated regression method can be applied to see this problem in different viewpoint.

\section{Acknowledgments}

Firstly, I would like to express my infinite gratitude to Allah SWT for the countless blessings, so that I can finish this research. I would also like to express my special gratitude to my mother, Farida, and my wife, Fiskha Kusumawati, for the whole supports and I present this research especially for my children, Kayyisah Dahayu Azkadina, Dayyan Hanif Ghaniahsan, and Daneen Disga Fahmida, so they can surpass my achievement.

I would also show my special gratitude to Asterina Zarnia, Rusman Affandi, Dr. Abdul Erumban and Tarek Harchaoui, Ph. D. for all valuable inputs, guidance, and critics during the preparation of this thesis.

I also acknowledge the Ministry of Finance of the Republic of Indonesia for granting me precious opportunity to take Master program and live abroad to broaden my experience and perspective of thinking, which I wish I can use it in my future career in the Ministry of Finance.

Finally, I want to thank my family, my friends, and everyone for supporting me throughout the process of completing this master program. Thank you.

\section{References}

Acemoglu, D., \& Autor, D. (2010). Skills, Tasks and Technologies: Implications for Employment and Earnings. NBER Working Paper, 16082.

Acharya, R. C. (2016). ICT use and total factor productivity growth: Intangible capital or productive externalities? Oxford Economic Papers, 68(1), 16-39. https://doi.org/10.1093/oep/gpv058

Adam, K., \& Zhu, J. (2016). Price-Level Changes and the Redistribution of Nominal Wealth across the Euro Area. Journal of the European Economic Association, 14(4), 871-906. https://doi.org/10.1111/jeea.12155

Afandi, A., Rantung, V. P., \& Marashdeh, H. (2017). Determinant of income inequality in Indonesia. Economic Journal of Emerging Markets, 9(2), 159-171. https://doi.org/10.20885/ejem.vol9.iss2.art5

Aghaei, M., \& Rezagholizadeh, M. (2017). The Impact of Information and Communication Technology (ICT) on Economic Growth in the OIC Countries. Economic and Environmental Studies, 17, 257-258.

Agüero, A., \& de Silva, H. (2011). Bottom of the Pyramid Expenditure Patterns on Mobile Phone Services in Selected Emerging Asian Countries. SSRN Electronic Journal, 7(3), 19-32. https://doi.org/10.2139/ssrn.1551775

Ahmed, E. M. (2017). ICT and Human Capital Spillover Effects in Achieving Sustainable East Asian Knowledge-Based Economies. Journal of the Knowledge Economy, 8(3), 1086-1112. https://doi.org/10.1007/s13132-016-0430-4

Akinbobola, T. O., \& Saibu, M. O. O. (2004). Income inequality, unemployment, and poverty in Nigeria: a vector autoregressive approach. The Journal of Policy Reform, 7(3), 175-183. https://doi.org/10.1080/1384128042000261800

Asongu, S. A. (2015). The impact of mobile phone penetration on African inequality. International Journal of Social Economics, 42, 706-716.

Atkinson, A. C. (2003). Income Inequality in OECD Countries: Data and Explanations. CESifo Working Paper, 881.

Autor, D. H., Katz, L. F., \& Krueger, A. B. (1997). Computing Inequality: Have Computers Changed The Labor Market?

Bahmani-Oskooee, M., Hegerty, S. W., \& Wilmeth, H. (2008). Short-Run and Long-Run Determinants of Income Inequality: Evidence from 16 Countries. Journal of Post Keynesian Economics, 30(3), 463484. https://doi.org/10.2753/PKEO

Bound, J., \& Johnson, G. (1989). Changes in the Structure of Wages during the 1980's: An Evaluation of Alternative Explanations. NBER Working Paper, 2983(May). Retrieved from 
http://www.nber.org/papers/w2983

Bourdeau de Fontenay, A., \& Beltran, F. (2008). Inequality and economic growth: Should we be concerned by the digital divide? International Telecommunications Society, 17(May), 1-37.

Brynjolfsson, E., Hu, Y. J., \& Smith, M. D. (2003). Consumer surplus in the digital economy: Estimating the value of increased product variety at online booksellers. Management Science, 49(11), 1580-1596. https://doi.org/10.1287/mnsc.49.11.1580.20580

Byrne, D., \& Corrado, C. (2017). ICT Prices and ICT Services: What do they tell us about Productivity and Technology? Finance and Economics Discussion Series, 2017(015), 150-181. https://doi.org/10.17016/feds.2017.015

Cecchini, S. (2003). Tapping ICT to reduce poverty in rural India. IEEE Technology and Society Magazine, 22(2 SPEC), 20-27. https://doi.org/10.1109/MTAS.2003.1216239

Cette, G., MAIRESSE, J., Kocoglu, Y., \& Mairesse, J. (2002). Diffusion of ICTs and Growth of the French Economy over the Long-term, 1980-2000. International Productivity Monitor, 4, 27--38.

Chinn, M. D., \& Fairlie, R. W. (2004). The Determinants of the Global Digital Divide. NBER Working Paper, 10686. Retrieved from http://www.ssc.wisc.edu/ mchinn/chinn_fairlie.pdf

Colecchia, A., \& Schreyer, P. (2003). The Contribution of Information and Comunication Technologies to Economic Growth in Nine OECD Countries. OECD Economic Studies, 2002(1), 153-171. https://doi.org/10.1787/eco studies-v2002-art5-en

Cramer, J., \& Krueger, A. B. (2016). Disruptive change in the taxi business: The case of uber. American Economic Review, 106(5), 177-182. https://doi.org/10.1257/aer.p20161002

Dartanto, T., Yuan, E. Z. W., \& Sofiyandi, Y. (2017). Two Decades of Structural Transformation And Dynamics of Income Equality in Indonesia. Asian Development Bank Institute, (783). Retrieved from https://www.adb.org/sites/default/files/publication/371316/adbi-wp783.pdf

Erumban, Abdul Azeez, \& Timmer, M. P. (2012). The Dark Side of Creative Destruction: Innovation and Retirement of Capital. Industrial and Corporate Change, 21(5), 1149-1174. https://doi.org/10.1093/icc/dts005

Erumban, Abdul A., \& Das, D. K. (2016). Information and communication technology and economic growth in India. Telecommunications Policy, 40(5), 412-431. https://doi.org/10.1016/j.telpol.2015.08.006

Flor, A. (2016). ICT pathways to poverty reduction: empirical evidence from East and Southern Africa. Information Technology for Development https://doi.org/10.1080/02681102.2014.923595

Goesling, B. (2001). Changing Income Inequalities within and between Nations : New Evidence. American Socilogical Review, 66(5), 745-761.

Hübler, M., \& Hartje, R. (2016). Are smartphones smart for economic development? Economics Letters, 141(2016), 130-133. https://doi.org/10.1016/j.econlet.2016.02.001

Irvine, W., \& Anderson, A. R. (2008). ICT (Information Communication Technology), Peripheraility and Smaller Hospitality Business in Soctland. International Journal of Entreprenurial Behaviour \& Research, 14(4), 200-218.

James, J. (2014). Mobile Phone Use in Africa: Implications for Inequality and the Digital Divide. Social Science Computer Review, 32(1), 113-116. https://doi.org/10.1177/0894439313503766

Jensen, R. (2007). The digital provide: Information (technology), market performance, and welfare in the South Indian fisheries sector. Quarterly Journal of Economics, 122(3), 879-924. https://doi.org/10.1162/qjec.122.3.879

Kim, D. (2018). Consumer welfare of informative messages via mobile instant messenger: A case of KakaoTalk's Info-Talk. Telematics and Informatics, 35(6), 1643-1655. https://doi.org/10.1016/j.tele.2018.04.010

Lee, J. W., \& Wie, D. (2015). Technological change, skill demand, and wage inequality: Evidence from Indonesia. World Development, 67, 238-250. https://doi.org/10.1016/j.worlddev.2014.10.020

Lindbeck, A., \& Wikstrom, S. (2000). The ICT revolution in consumer product markets. Consumption Markets \& Culture, 4(1), 77-99. https://doi.org/10.1080/10253866.2000.9670350

Mbuyisa, B., \& Leonard, A. (2017). The Role of ICT Use in SMEs Towards Poverty Reduction: A Systematic Literature Review. Journal of International Development, 29(2), 159-197. https://doi.org/10.1002/jid.3258

McNamara, K. S. (2003). Information and Communication Technologies, Poverty and Development: Learning from Experience. InfoDev. https://doi.org/10.12968/bjon.2017.26.20.1092

Meh, C. A., \& Terajima, Y. (2011). Inflation, nominal portfolios, and wealth redistribution in Canada. THe Canadian Journal of Economics, 44(4), 1369-1402. 
Michaels Guy, Natraj Ashwini, V. R. J. (2014). Has ICT Polarized Skill Demand? Evidence from Eleven Countries over 25 Years. Review of Economics and Statistics, 96(1), 60-77. https://doi.org/10.1162/REST

Monga, C., Lin, J. Y., Aker, J. C., \& Blumenstock, J. E. (2014). The Economic Impacts of New Technologies in Africa. The Oxford Handbook of Africa and Economics, (November), 1-15. https://doi.org/10.1093/oxfordhb/9780199687107.013.021

Norris, P. (2001). Digital Divide: Civic Engagement, Information Poverty, and The Internet Worldwide. Retrieved

from https://www.academia.edu/2750047/Digital_divide_Civic_engagement_information_poverty_and _the_Internet_worldwide

Novalia, Y. (2014). Dampak perubahan struktur ekonomi terhadap ketimpangan distribusi pendapatan di Indonesia [Tesis]. Tesis.

Panizza, U. (1999). Income Inequality and Economic Growth: Evidence from the American Data. Working Paper, 404.

Pick, J. B., Sarkar, A., \& Johnson, J. (2015). United States digital divide: State level analysis of spatial clustering and multivariate determinants of ICT utilization. Socio-Economic Planning Sciences, 49, 16-32. https://doi.org/10.1016/j.seps.2014.09.001

Saunders, P. (2002). The direct and indirect effects of unemployment on poverty and inequality. SPRC Discussion Paper No. 118, (118), 1-31.

Silva, H. de, \& Ratnadiwakara, D. (2008). Using ICT to reduce transaction costs in agriculture through better communication: A case study from Sri Lanka. LIRNEasia, Colombo, Sri Lanka, (January), 20. Retrieved

from http://unpan1.un.org/intradoc/groups/public/documents/UNPAN/UNPAN037348.pdf\%5CnSilva_ 2008_Using ICT to reduce transaction costs in agriculture through better communication A case study from Sri Lanka (2).pdf

Spiezia, V. (2013). ICT investments and productivity. OECD Journal: Economic Studies, 2012(1), $199-211$. https://doi.org/10.1787/eco_studies-2012-5k8xdhj4tv0t

Stanley, T. D., Doucouliagos, H., \& Steel, P. (2018). Does Ict Generate Economic Growth? a MetaRegression Analysis. Journal of Economic Surveys, 32(3), 705-726. https://doi.org/10.1111/joes.12211

Timmer, M. P., \& van Ark, B. (2005). Does information and communication technology drive EU-US productivity growth differentials? Oxford Economic Papers, 57(4), 693-716. https://doi.org/10.1093/oep/gpi032

Tregenna, F. (2011). Earnings inequality and unemployment in South Africa. International Review of Applied Economics, 25(5), 585-598. https://doi.org/10.1080/02692171.2011.557053

van Ark, B., Gupta, A., \& Erumban, A. A. (2013). The Linked World: Measuring the Contribution of ICT to Economic Growth. The Conference Board.

Ziemba, E. (2016). Factors affecting the adoption and usage of ICTs within Polish households. Interdisciplinary Journal of Information, Knowledge, and Management, 11, 89-113. https://doi.org/10.28945/3507 